ture. The experiment on p. 135, "to find the temperature of a furnace," is misleading. A piece of nickel is placed in the furnace and then transferred to a calorimeter containing water, the rise of temperature being noted. At $1000^{\circ} \mathrm{C}$. the specific heat of nickel differs very considerably from the value at the ordinary temperature. On p. 163 the authors cite the boiling of water in a paper vessel as an effect similar to that obtaining in a boiler plate. In a boiler plate of good conducting material there is, of course, little difference of temperature between the two sides, but paper is a bad conductor of heat, and the reason the paper does not burn is due to an entirely different cause. When water is boiled in a paper vessel the escape of vapour through the paper is considerable, and the flame is usually quite $\frac{1}{4}$ in. from the paper.

(3) Mr. Johnson's book is written for the ambitious artisan, and is based upon notes made by the author during nine years' teaching experience in evening vocational and technical schools in the United States. For its perusal no further mathematical knowledge is required than the elementary rules of arithmetic, simple equations, and the trigonometrical ratios of an angle. It includes chapters on engineering measuring instruments, calculations of areas and weights, pulleys and belting, gearing, properties and strength of materials. Two chapters dealing with the elements of statics are fully illustrated by practical examples from the workshop. The book is clearly written and the diagrams are well executed. A large number of numerical exercises are interspersed in the text, but the workman bent on self-improvement would find the book of considerably greater value if the author had furnished answers to these examples.

(4) The collection of problems by Prof. Ryan (upwards of one hundred) is intended to be used with Morecroft's elementary text-book on "Continuous and Alternating Current Machinery." No answers are provided.

\section{METALLURGY OF GOLD.}

The Metallurgy of Gold. By Sir T. K. Rose. Sixth edition. Pp. xix +601 . (London: C. Griffin and Co., Ltd., I9I5.) Price 22s. 6d. net.

\section{CIR THOMAS ROSE'S "Metallurgy of Gold"} D has been recognised for the last twenty years as the best general treatise on the metallurgy of the metal; the appearance of this new edition, which by revision and expansion is practically a new book, will hence be warmly welcomed by all metallurgists. Since the last edition was pub- lished in 1906 the changes which have been introduced in the metallurgy of gold have been greater than those in any other metal; the need for a new edition of the book was therefore imperative, and this need has been admirably satisfied in the present volume.

As stated in the preface, "the most important function which a book on metallurgy has to fulfil is to help those who are taking part in attempts to improve existing practice," and with that aim in view the whole book has been thorougly revised and much new matter added. The early chapters, which have been rewritten and greatly enlarged, now contain a remarkably full and accurate account of the properties of gold, its compounds and alloys, and throughout the volume special attention is given to the principles underlying the various practical operations involved in the extraction of the metal, and in the refining and preparation of gold bullion for the market and for minting. In this connection it will be admitted by all that without a knowledge and clear understanding of these properties and principles, an acquaintance with mere practical details, however extensive, will not be sufficient to enable the metallurgist to cope successfully with the difficult problems which will confront him from time to time in the practical operations of the metallurgy of gold.

The remarkable success which during recent years has attended the introduction of the filtration of slime on the vacuum principle has led to a complete change in the functions of the stamp battery as a crushing machine; the chapters dealing with stamps, crushing, fine grinding, and amalgamating machinery have hence been largely rewritten and brought thoroughly up to date.

But it is in the cyanide process that we find the most conspicuous changes and advances, hence the chapters devoted to it are for the most part new. These chapters contain an authoritative account of the various mechanical developments of the process of the principles involved in working it, and of the latest and most approved practice in modern cyanide works. Detailed descriptions are given of the plant and appliances in current practice for the treatment of sand, and of the various agitators, vacuum filters, filter presses, \&c., employed in the treatment of slime. Further, the reactions which take place in the cyanide process, the conditions necessary for the success of the various operations, and the best means of carrying them out, from the crushing of the ore to obtaining the gold as bullion, are all given clearly and concisely. In chapter xvii. modern practice is exemplified by the operations at typical plants. These chapters contain, in fact, 
an account of the process of the greatest value to those practically engaged in cyaniding, and aiso to students.

The author's chapter on the electrolytic parting of gold and silver, which bids fair to displace the old methods of treatment with sulphuric or nitric acids, is one of the most important in the book. It is not only an excellent résumé of the practice followed, but also embraces the valuable experimental work done by the author himself.

Of the chapters on the assay of gold ore and bullion it need only be said that they are worthy of the assayer of the Royal Mint.

Much care has been taken, as in previous editions, in quoting the sources of the information given throughout the book, and the wealth of references in the footnotes is a valuable bibliography of the literature of the subject.

We unreservedly commend the book as being indispensable, not only to students, but also, and especially, to all who are practically engaged in the metallurgy of gold. W. Gowland.

PSYCHICAL RESEARCH.

Apparitions and Thought-Transference: An Examination of the Evidence for Telepathy. By F. Podmore. New and enlarged edition. Pp. xviii +467 . (London: The Walter Scott Publishing Co., Ltd., I9I5.) Price $6 s$.

7 HIS is a new edition, in the Contemporary 1 Science series, of a book which still remains, after twenty-one years from its first appearance, one of the best introductions to the subject (see review in Nature, December 6, I894). The illustrative cases have now inevitably a rather ancient history appearance, and many of them are duplicated in other books, such as Myers's "Human Personality" and Sir Oliver Lodge's "Survival of Man"; it may be urged, therefore, that an entirely fresh treatment of the subject, with due attention to the experiments of Miss Miles and Miss Ramsden and to the S.P.R. cross-correspondences, would have been preferable to a rechauffé. Moreover, the author being dead, various slips occur: the American S.P.R. is no longer a branch of the English society ; the latter's publisher is now the firm of Maclehose, not $R$. Brimley Johnson; Dr. Sidis's name is wrongly spelt on p. 260 , as Sir Joseph Barnby's is in the index; and there is an inventive misprint of "Boding " for "Bodily" on p. 459, in the reference to Myers's "Human Personality." But these are not very important matters.

Mr. Podmore's thesis is that communication is possible between mind and mind otherwise than through the known channels of the senses. Beginning with the early mesmerists, who in some cases seem to have hypnotised patients at a distance, he proceeds to cases of transference of pain or of visual images, in the experiments of Dr. Liébeault and the Nancy school generally, and of Prof. and Mrs. Sidgwick and Sir Oliver Lodge; thence to spontaneous cases in dream or hallucination, culled largely from the monumental collection, "Phantasms of the Living," which is now out of print. Possible sources of error are carefully considered and allowed for, and the author's conclusion isquoting Prof. De Morgan-that either the thesis as above stated is a justified hypothesis, or we must say at leisure what David is reported to have said in his haste. And if the latter - if human testimony is completely untrustworthy-there is an end of history and various other sciences.

It is a somewhat remarkable fact, considering the newness and difficulty of the research, that the opinions expressed in the book would call for little alteration, after twenty-one years, if they were to be revised by a committee representative of the present leaders of the S.P.R. Probably their only qualifying remark would be that it is not quite as certain as Mr. Podmore thought that such phenomena as Mrs. Piper's are completely and truly explained by telepathy. Other hypotheses, more far-reaching but not less essentially scientific if we can free our minds from prejudice, are possible.

Finally, we may remark that the present war presents a scientifically good if morally regrettable opportunity of making exceptional records in psychical research. There is reason to believe that a moment of stress, of great excitement or emotion or concentration, is favourable to the initiation of a telepathic impulse. It is probable that many people at home have become aware of their soldier-relative's wound before the news arrived by normal means. A dream or hallucination may show the nature of the wound, as in Mr. Colt's case in "Human Personality." These experiences should be at once recorded; and if the percipient will send the account, before verification, to the S.P.R., 20 Hanover Square, W., he or she may be assured of sympathetic interest and may be furnishing useful data. Obviously, expectation will account for some of these experiences; but when there is much true detail other suppositions may become necessary. J. A. H.

\section{OUR BOOKSHELF.}

Penrose's Annual, r9i6. Vol. xxi. The Process Year Book. Edited by W. Gamble. Pp. r12+ illustrations. (London: Percy Lund, Humphries and Co., Ltd., I9I6.) Price 5s. net. IN taking up an annual that deals with the progress of a handicraft at such a time as this, one naturally looks for the effects of the unprecedented conditions that now afflict us. On the
No. 24I3, VOL. 96]

@1916 Nature Publishing Group 